\section{Disaggregating health inequalities within Rio de Janeiro, Brazil, 2002-2010, by applying an urban health inequality index}

\author{
Desagregando desigualdades na saúde no Rio de \\ Janeiro, Brasil, 2002-2010, através da aplicação \\ de um índice urbano de desigualdade de saúde
}

\author{
Disgregando desigualdades en el ámbito de \\ la salud en Río de Janeiro, Brasil, 2002-2010, \\ mediante la aplicación de un índice urbano \\ de desigualdad en salud
}

\author{
Martin Bortz 1 \\ Megumi Kano 2 \\ Heribert Ramroth 1 \\ Christovam Barcellos 3 \\ Scott R. Weaver 4 \\ Richard Rothenberg 4 \\ Monica Magalhães ${ }^{3}$
}

\author{
${ }^{1}$ Institute of Public Health, \\ University of Heidelberg, \\ Heidelberg, Germany. \\ 2 WHO Centre for Health \\ Development, Kobe, Japan. \\ 3 Instituto de Comunicação \\ e Informação Científica \\ e Tecnológica em Saúde, \\ Fundação Oswaldo Cruz, Rio \\ de Janeiro, Brasil. \\ 4 Georgia State University \\ School of Public Health, \\ Atlanta, U.S.A. \\ Correspondence \\ M. Bortz \\ Institute of Public Health. \\ Im Neuenheimer Feld \\ 324, Heidelberg / Baden- \\ Wuerttemberg - 69120, \\ Germany. \\ mail@martinbortz.de
}

\begin{abstract}
An urban health index (UHI) was used to quantify health inequalities within Rio de Janeiro, Brazil, for the years 2002-2010. Eight main health indicators were generated at the ward level using mortality data. The indicators were combined to form the index. The distribution of the rank ordered UHI-values provides information on inequality among wards, using the ratio of the extremes and the gradient of the middle values. Over the decade the ratio of extremes in 2010 declined relative to 2002 (1.57 vs. 1.32) as did the slope of the middle values (0.23 vs. 0.16). A spatial division between the affluent south and the deprived north and east is still visible. The UHI correlated on an ecological ward-level with socioeconomic and urban environment indicators like square meter price of apartments $(0.54, p<0.01)$, low education of mother $(-0.61$, $p<0.01)$, low income $(-0.62, p<0.01)$ and proportion of black ethnicity $(-0.55, p<0.01)$. The results suggest that population health and equity have improved in Rio de Janeiro in the last decade though some familiar patterns of spatial inequality remain.
\end{abstract}

Health Status Indicators; Health Inequalities; Urban Health

\section{Resumo}

Um índice de saúde urbana foi utilizado para quantificar desigualdades na saúde no Rio de Janeiro, Brasil, 2002-2010. Oito indicadores de saúde foram gerados no nível dos bairros utilizando dados de mortalidade. Os indicadores foram combinados para formar o índice. A distribuição ordenada dos valores do indice fornece informações sobre a desigualdade entre os bairros, por meio da relação entre os extremos e o gradiente dos valores médios. Ao longo da década, a proporção dos extremos caiu em 2010 em relação a 2002 (1,57 vs. 1,32), assim como a inclinação dos valores médios $(0,23$ vs. 0,16$)$. A divisão espacial entre o sul afluente e o norte carente está ainda visível. Os valores do índice correlacionam com indicadores socioeconômicos e urbanos como o preço do metro quadrado de apartamentos $(0,54, p<0,01)$, baixa escolaridade da mãe $(-0,61, p<0,01)$, baixa renda $(-0,62, p<0,01)$ e proporção de pretos étni$\cos (-0,55, p<0,01)$. Os resultados sugerem que a equidade na saúde no nível da população tem melhorado no Rio de Janeiro na última década, embora padrões familiares da desigualdade espacial permaneçam.

Indicadores Básicos de Saúde; Desigualdades em Saúde; Saúde Urbana 


\section{Introduction}

Latin America in general, and Brazil in particular, experienced rapid urbanization during the period between the 1960s and 1990s. The area is second only to Asia in the proliferation of megacities. With $79 \%$ of the population living in urban areas, Brazil is already more urbanized than Europe 1 . As one of the five emerging economies of the world, referred to as BRICS (Brazil, Russia, India, China, South Africa), Brazil became a regional model in Latin America during the last decade with a prospering economy linked to new social policies.

\section{Urban development in Rio de Janeiro}

The city of Rio de Janeiro, however, is characterized by a deep socioeconomic division, where the urban space allocation of the city dwellers is strongly influenced by income 2 . Mean income tends to decrease from south (the upper-class neighborhoods) to north (the suburbs) and from east (the city center) to west. These patterns predated urban planning efforts in the $20^{\text {th }}$ century, since rising social inequalities were a product of a fast, massive rural-to-urban migration in combination with insufficient industrialization and inadequate infusion of national capital into Brasilia during the 1960s. Lack of housing, insufficient transportation, informal employment, violence, marginalization of the poor and a lack of public services increased the inequalities. Informal settlements, known as favelas, sprung up excessively (often in proximity to high income areas) and formed Rio de Janeiro's characteristic socioeconomic mosaic. Since re-democratization in 1984, Rio de Janeiro has adopted various urban reforms and social redisitribution policies that have culminated in the current process of urban renewal 3. A whole package of interventions, focusing on neighborhood-upgrading, social housing, security, primary health care and transportation 4,5 was created to integrate former marginalized areas and generate permanent improvements from mega-events 6 , such as the 2014 FIFA World Cup and the 2016 Summer Olympics Games. The process of urban reinvention does not come without controversy, however. Some investigators argue that the majority of urban interventions have only selective impact and their influence on health outcomes may not be detectable 7,8,9.

Such controversy is evident in assessing Brazil's public health status. There have been notable advances in Brazil's public health in terms of access and quality 10,11. But there remains a triple burden of disease. Infectious diseases like dengue, tuberculosis and HIV continue to have a significant impact on urban population health $12,13,14$. There are also growing rates of non-communicable diseases (NCD), such as diabetes, with Brazil likely to bear one of the world's highest health burdens 15 . Violence and homicide are also concentrated in urban settings 16 . Patterns of population health that mirror socioeconomic indicators have often been well-demonstrated, mainly for issues such as maternal-infant health violence, and quality of primary health care services 17,18. Previous studies recognized that Rio de Janeiro is divided into an affluent south and deprived areas in the north and east, where disadvantaged populations in Rio de Janeiro face an excess burden of poor health 19,20,21,22.

\section{Intra-urban health perspective}

An intra-urban perspective is critical to visualize inequalities in health outcomes and health development. Population density and heterogeneity of the type seen in mega-cities can obscure differences; the level of analysis has to be a geographical urban unit small enough to make distinctions within urban areas, in order to capture the inequality in health. Since health is now widely viewed as a product of underlying social determinants that act on the individual 23,24 , such detailed analysis is key to identifying important differences. In this context, the urban space can be understood as a determinant of health that concentrates historic, economic, social, political, and environmental conditions that influence health. Space is as much producer as product of these inequalities 25 .

In this paper an approach based on an urban health inequality index 26 is used to disaggregate and quantify health within the city of Rio de Janeiro for the years 2002 to 2010. Different from previous studies that partially introduced inequality indicators in Rio de Janeiro 17 , the Urban Health Index (UHI) can incorporate a broad range of key urban health issues through aggregation of various indicators. This approach makes it possible to demonstrate inequality in its spatial dimension, and can encompass a whole municipality or smaller configuration, as well as synthesizing different aspects of health inequality in a comprehensible metric. When applied over time, the UHI can also follow the trend of health development. In a broader context, such an analysis can draw inferences about how population health, and specifically health inequalities, may have been influenced by the economic, historic and functional structuring of the city.

Research on urban health inequalities in Brazil is of great relevance. Not only economically but also in terms of health, low- and middle-in- 
come countries are thought to be brought into alignment with high-income countries through urbanization 27 . At the center of this controversy stands the question of whether cities are able to provide an urban health advantage for sustainable development 28; particularly as Brazilian cities concentrate extreme inequalities in income, education, housing, safety and health 10,29. The UHI serves as an advocator for and a measure of trends in urban life quality.

\section{Methods}

The Municipality of Rio de Janeiro, where this ecological-spatial study was performed, has five planning areas with 22 administrative districts and 160 wards. Mortality events at ward level for the years 2000 to 2012 are the basis for this analysis. Public data were obtained from the routine national health information system (DATASUS; http://www2.datasus.gov.br/DATASUS.html, accessed on 15/Sep/2014) and its municipal branch (TABNET; http://www0.rio.rj.gov.br/tab net.html, accessed on 15/Sep/2014). The Ethics Committee granted exempt status for this project since only previously collected, publicly available, non-identified data were used. Two registries of the municipal TABNET were accessed: the mortality registry (Sistema de Informações sobre Mortalitade [SIM]) and the birth registry (Sistema de Informação sobre Nascidos Vivos [SINASC]). Deaths were referenced using the variables "ward of residency" and "Planning Area" recorded in the death certificates.

Considering the health burdens mentioned in the introduction, eight causes of mortality were selected to form the UHI for Rio de Janeiro (ICD-10 codes are indicated in parentheses): diabetes (E10-E14), ischemic heart disease (I20I25), breast and cervix cancer (C50, C53), HIV (B20-B24), tuberculosis (A15-A19), infant deaths, traffic accident (V01-V99) and homicide (X85Y09). They represent four key urban health conditions (i.e. NCD, infectious disease, child health and injuries). The selection of these causes of mortality was based on the recommendation obtained through several urban health expert roundtables 30 . The component indicators represent socially sensitive diseases since they are partially or completely preventable by means of health sectorial or inter-sectorial policies. To calculate ward mortality rates per 100,000 inhabitants, population data were taken from the Brazilian Institute of Geography and Statistics (IBGE; http://www.ibge.gov.br/english.html, accessed on 15/Sep/2014) census counts in 2000 and 2010 in census tract units and then aggregated into wards and administrative districts. The population data for the years in between the census years were generated through linear interpolation.

For bivariate correlation analysis, indicators for health determinants were calculated at wardlevel as proportions of total population by using data from the IBGE demographic census 2010 [illiteracy; persons with income below double the minimum wage (approximately USD 600 per month); persons with income between 5 and 10 times the minimum wage (approximately USD 1,500 to 3,000 per month); the IBGEs' main ethnical classification of the population into black, white and mulatto; people aged over 60; people aged under 20] and the birth registry using the newborn register SINASC (mothers aged less than 20; premature birth before week 37; mothers with 4 to 7 years of education; mothers with more than 12 years of education; mothers with less than 3 prenatal consults; mothers with more than 7 prenatal consults).

Wards with a population of less than 5,000 were merged with their biggest neighbor, resulting in a total of 142 wards for analysis with an average population size of 46,176 (range, 5,466 to 328,370 ). As a control for fluctuation, a 5-year weighted mean was applied to the mortality rates in order to create stability throughout time. The mortality rate for the year of interest $\mathrm{MR}_{(\mathrm{t})}$ was weighted 0.4 times whereas the respective two neighboring years $\left(\mathrm{MR}_{(\mathrm{t}-/+1 ; 2)}\right)$ were weighted 0.2 and 0.1 . Due to the weighting, the results of the first and latest two years (2000, 2001, 2011, 2012) were not counted in the final analysis. After comparative calculations the 5-year weighting was more capable of controlling for fluctuations than the 3-point moving median.

Weights were applied to the mortality rates (MR) of five consecutive years (t) to calculate the five-year weighted mean:

$\mathrm{MR}_{\text {weight }}=\mathrm{MR}_{(\mathrm{t}-2)} \times 0.1+\mathrm{MR}_{(\mathrm{t}-1)} \times 0.2+\mathrm{MR}_{(\mathrm{t})} \times 0.4$ $+\mathrm{MR}_{(\mathrm{t}+1)} \times 0.2+\mathrm{MR}_{(\mathrm{t}+2)} \times 0.1$

The Standard Mortality Ratio (SMR) is recommended for small sample sizes, but nevertheless, age-adjustment based on small numbers exhibits large random variation, specifically when less than 20 total health events can be observed over all age-groups 31 . To avoid further manipulation of the data indirect age-standardization for every single ward was only applied to selected indicators (using 10-year specific age-strata, for both sexes combined, and using national agespecific mortality rates to be applied to the ward's population). Age-adjustment was applied to the mortality indicators for diabetes, ischemic heart disease, and cervix and breast cancer, which are more strongly influenced by aging compared to other indicators. 
The methodology for the construction of the UHI 26 is adapted from the Human Development Index (HDI) 32. Briefly, to transform the health rates into a dimensionless number between 0 and $1(I S)$ the observed mortality rate $\left(I_{i}\right)$ is standardized as a proportion of the range, using a single maximum $(\max (I))$ and minimum $(\min (I))$ value that was observed among the study units for all of the years from 2002 to 2012.

$$
I^{S}=\frac{I_{i}-\min (I)}{\max (I)-\min (I)}
$$

In the next step, the UHI is computed as the geometric mean of the eight standardized indicators

$$
G=\left(\prod_{i=1}^{m} I_{i}^{S}\right)^{\frac{1}{m}},
$$

where $m=8$. For the purposes of the calculation, a lower goalpost value than the minimum was used $(\min (I)-1)$, to avoid 0 values when calculating the geometric mean. In order to keep interpretation in line with the HDI, the final index values were reversed (1-Index) so that high index values are equal to better health outcomes. When the index values are ranked, the resulting graph typically has an inverted-S shape with steeper slopes in both extremes. Two characteristics of the curve were examined to evaluate the health inequalities as shown in the distribution: first, the ratio of the mean of the extreme upper and lower $10 \%$ (i.e. the disparity ratio), and second, the degree of inclination, or slope, of the middle $80 \%$ of the distribution curve (i.e. the disparity gradient). The comparative slope was made on a horizontal scale with intervals $1 / \mathrm{n}$, to keep it within $(0,1)$ boundaries and permit comparability.

The results of the UHI and their spatial distribution were mapped and visualized in a choropleth by using the ArcGIS software (http://www. esri.com/software/arcgis/index.html), permitting analysis and interpretation of spatial patterns of the health inequalities. Local autocorrelation on the ward level was revealed through calculation of the Local Moran's Index (LISA) 33,34. It computes the correlation (or degree of similarity or dissimilarity) between an area's value and the average of surrounding neighbor values. Positive values imply that a unit has similar high or low values with its neighboring units. Negative values indicate that a unit has dissimilar values with its neighbors. For cluster analysis the correlation between an area's value and the average value from a randomly chosen set of areas is calculated. The correlations follow a normal distribution. If the area and its neighbors all have values that are above the mean, this is interpreted as a significant cluster of places with "high" values.
The results can be visualized in maps in order to facilitate the detection of a cluster of high values $(\mathrm{HH})$ or low values (LL) or to highlight contrasts (HL, LH). Finally, correlation analyses were performed to explore possible associations between social and urban environmental indicators and the UHI.

\section{Results}

The distribution of the ward-level index values by their rank order for 2002 and 2010 demonstrates the typical shape for the UHI, with some attenuation at the upper end (Figure 1). For 2010, higher index values are observed overall with a flatter inclination and a considerable improvement in the lower $10 \%$ extreme in comparison to 2002 . The disparity ratio (i.e. the ratio of the upper and lower $10 \%$ in the UHI distribution) fell from 1.57 to 1.35 during the study period (Table 1 ). The disparity gradient (i.e. the slope of the middle $80 \%$ of the UHI distribution) also declined, reaching a nadir of 0.18 in 2010. Both these trends reflect an overall decrease in the range of the UHI distribution. As shown in Figure 1, there were particularly large positive shifts in the lower percentiles of the UHI distribution that caused the reduction of the width of the UHI distribution. The changes over time at the lower extreme of the distribution are more marked than at the higher extreme. Specifically, the minimum UHI value increased from 0.16 in 2002 to 0.55 in 2010, whereas the maximum value only changed from 0.95 to 0.96 over the same period.

When viewed singly, similar results were found for most of the indicators that compose the index. The majority of the indicators demonstrate falling ratios and declining slopes, with the exception that diabetes and tuberculosis recorded a new increase since 2006 and 2007. According to the index distribution parameters wider health inequalities were observed for ischemic heart diseases and infant mortality, while HIV/AIDS, tuberculosis and homicides present a more uniform distribution among the city wards.

The spatial distribution of the ward-level UHI values, visualized for the Municipality of Rio de Janeiro, reflects the improvement observed from 2002 to 2010 (Figure 2). However, low index values are still observed in the northern districts and especially near the city center, while the northeastern areas show a very heterogeneous picture in 2010. The highest (best) index values were concentrated in the southern region, and they extend more widely in 2010.

After applying the LISA (Figure 3), it is shown that in 2010 the southern areas form a statisti- 


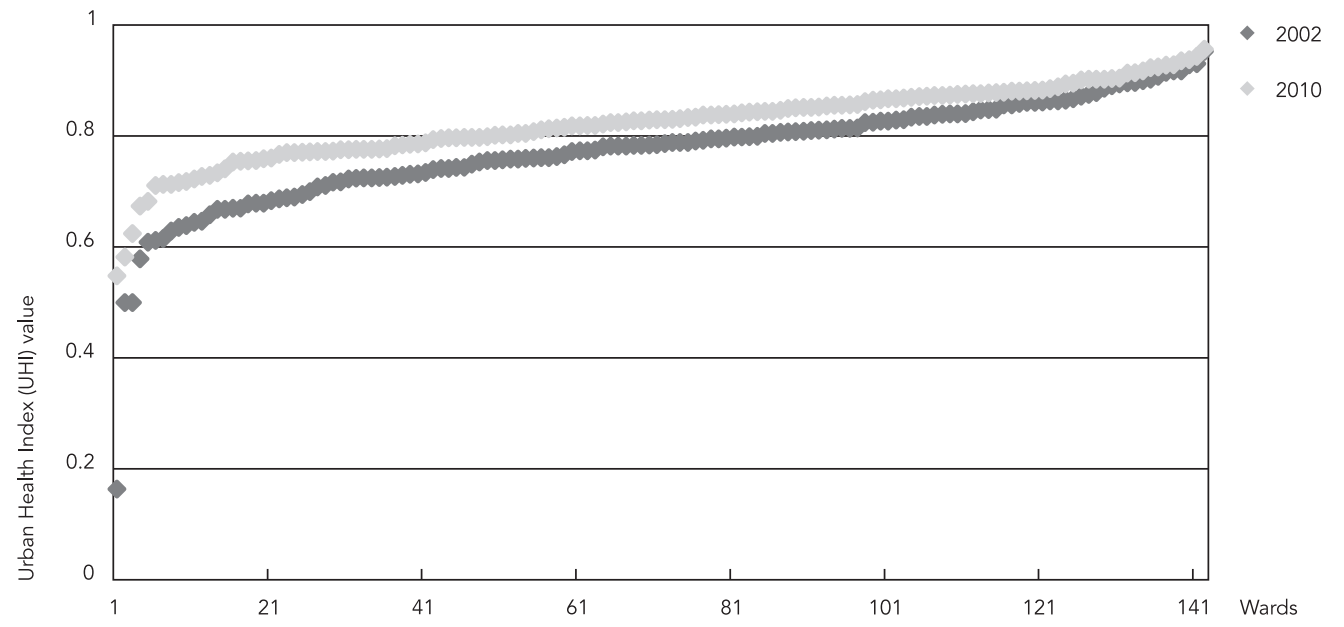

cally significant cluster of high index values with the exception of the two favelas. Clusters of low index values and nuclei of contrasting high-low wards are both found in the northeast region. A significant divide of high-low areas is presented between a modern ward (high) and its northern neighborhood (low).

Bivariate correlation analysis at ward level between a few selected urban environment indicators and UHI (Table 2) reveal consistently high and significant correlation coefficients. The correlation with the UHI is the highest for "apartment price per square meter" (0.54) and is also statistically significant for "distance from Lagoa" (an artificially defined center of upperclass neighborhoods) (-0.30). Statistically significant correlations also exist between the UHI and Social Determinants of Health (SDH), such as education, income and race. Mortality indicators for diabetes, tuberculosis, homicide and infant mortality generally showed higher correlation coefficients with the socio-environmental determinants compared to the other mortality indicators.

\section{Discussion}

\section{UHI reveals reduction of health inequalities}

According to the results of the UHI analysis, an overall reduction of health inequalities among wards is seen, suggesting that the health equity situation improved in Rio de Janeiro in the last decade. Average ward-level UHI values were higher in 2010 than in 2002 indicating improved levels of population health. At the same time, the disparity ratio and slope of the UHI distribution across wards came down. Particularly the wards with low index values in 2002 improved their health outcomes over the decade. This is because extremely high mortality rates of the magnitude observed in 2002 were brought down in the following years. The rapid improvement in mortality may not be fully explained by new social policies, but lend general support to their impact.

Positive economic developments within Brazil could have had an effect on this observed improvement in the urban health equity situation. Several innovative redistributive policies have been implemented that were able to strengthen the position of the poor and extend the social security system, such as the organization of the unified health system in 1988 35,36. Brazil also has one of the largest antiretroviral and tuberculosis treatment programs amongst middle-income countries 37 . It is not only the health sector but underlying social determinants that have likely been improved as a result. On the urban level, numerous urban reforms have been concerned with redefining the state's public services (for example the package of urban interventions in preparation for the 2016 Olympic Games 6,38). But it is still not clear if these urban renewal projects 
Descriptive statistics of the Urban Health Index (UHI) and its component mortality indicators in Rio de Janeiro Municipality, Brasil, 2002 to 2010.

\begin{tabular}{|c|c|c|c|c|c|c|c|c|c|}
\hline & 2002 & 2003 & 2004 & 2005 & 2006 & 2007 & 2008 & 2009 & 2010 \\
\hline \multicolumn{10}{|l|}{ UHI } \\
\hline Ratio & 1.57 & 1.55 & 1.54 & 1.50 & 1.50 & 1.40 & 1.35 & 1.34 & 1.35 \\
\hline Slope & 0.23 & 0.23 & 0.22 & 0.22 & 0.22 & 0.21 & 0.20 & 0.19 & 0.18 \\
\hline Mean & 0.77 & 0.78 & 0.79 & 0.79 & 0.79 & 0.80 & 0.81 & 0.82 & 0.82 \\
\hline SD & 0.10 & 0.10 & 0.10 & 0.09 & 0.09 & 0.08 & 0.07 & 0.07 & 0.07 \\
\hline Min. & 0.16 & 0.17 & 0.12 & 0.19 & 0.22 & 0.45 & 0.56 & 0.56 & 0.55 \\
\hline Max. & 0.95 & 0.95 & 0.94 & 0.93 & 0.92 & 0.93 & 0.94 & 0.95 & 0.96 \\
\hline Range & 0.79 & 0.78 & 0.81 & 0.74 & 0.70 & 0.48 & 0.38 & 0.39 & 0.41 \\
\hline \multicolumn{10}{|l|}{ Diabetes } \\
\hline Ratio & 2.55 & 2.34 & 2.17 & 2.04 & 1.99 & 2.09 & 2.09 & 2.13 & 2.12 \\
\hline Slope & 0.43 & 0.44 & 0.43 & 0.44 & 0.43 & 0.41 & 0.40 & 0.42 & 0.40 \\
\hline \multicolumn{10}{|c|}{ Ischaemic heart disease } \\
\hline Ratio & 3.42 & 3.03 & 2.62 & 2.64 & 2.57 & 2.22 & 2.09 & 2.01 & 1.92 \\
\hline Slope & 0.36 & 0.36 & 0.38 & 0.36 & 0.35 & 0.33 & 0.32 & 0.31 & 0.28 \\
\hline \multicolumn{10}{|c|}{ Breast and cervix cancer } \\
\hline Ratio & 2.25 & 2.26 & 2.01 & 1.95 & 1.99 & 2.01 & 1.83 & 1.84 & 1.86 \\
\hline Slope & 0.30 & 0.30 & 0.27 & 0.29 & 0.28 & 0.28 & 0.28 & 0.27 & 0.27 \\
\hline \multicolumn{10}{|l|}{ HIV } \\
\hline Ratio & 1.54 & 1.52 & 1.43 & 1.42 & 1.42 & 1.38 & 1.38 & 1.39 & 1.42 \\
\hline Slope & 0.19 & 0.19 & 0.19 & 0.17 & 0.17 & 0.16 & 0.16 & 0.16 & 0.16 \\
\hline \multicolumn{10}{|c|}{ Tuberculosis } \\
\hline Ratio & 1.66 & 1.56 & 1.52 & 1.40 & 1.40 & 1.36 & 1.42 & 1.46 & 1.46 \\
\hline Slope & 0.23 & 0.22 & 0.19 & 0.17 & 0.17 & 0.18 & 0.19 & 0.17 & 0.18 \\
\hline \multicolumn{10}{|c|}{ Infant mortality } \\
\hline Ratio & 2.60 & 2.12 & 2.54 & 2.63 & 2.63 & 2.25 & 2.17 & 2.16 & 2.37 \\
\hline Slope & 0.36 & 0.33 & 0.34 & 0.38 & 0.38 & 0.38 & 0.37 & 0.38 & 0.40 \\
\hline \multicolumn{10}{|c|}{ Traffic accident } \\
\hline Ratio & 1.77 & 1.80 & 1.77 & 1.75 & 1.75 & 1.59 & 1.47 & 1.38 & 1.34 \\
\hline Slope & 0.23 & 0.23 & 0.24 & 0.25 & 0.25 & 0.22 & 0.21 & 0.20 & 0.18 \\
\hline \multicolumn{10}{|l|}{ Homicide } \\
\hline Ratio & 1.62 & 1.62 & 1.57 & 1.46 & 1.46 & 1.30 & 1.24 & 1.21 & 1.19 \\
\hline Slope & 0.26 & 0.25 & 0.23 & 0.22 & 0.22 & 0.17 & 0.15 & 0.13 & 0.11 \\
\hline
\end{tabular}

are enough to decrease the huge social inequalities that exist. It is too early to make statements about their possible impacts.

\section{Spatial division hard to overcome}

Despite the positive trends, the findings also confirmed that the spatial segregation which has characterized Rio de Janeiro persists 19,20,21. For instance, the northern areas lag behind in health development, and the geo-spatial maps of the UHI (Figure 2) show that Rio de Janeiro still is a divided city with a persistent gap between north- ern and southern neighbors. When the UHI was generated for the five main Planning Areas that each correspond to the politically organized subregions (Center, South, Northeast, Southwest Northwest) for the years 2002 to 2010 (data not shown), the increase in UHI index values was observed but the established disparities within Planning Areas were unaltered. In particular, the center and the northern areas did not show a trend towards closing the gap with the southern regions. The trend of the northeast wards is unclear. This area shows evidence of improvements in UHI values in certain wards for 2010, but it is 

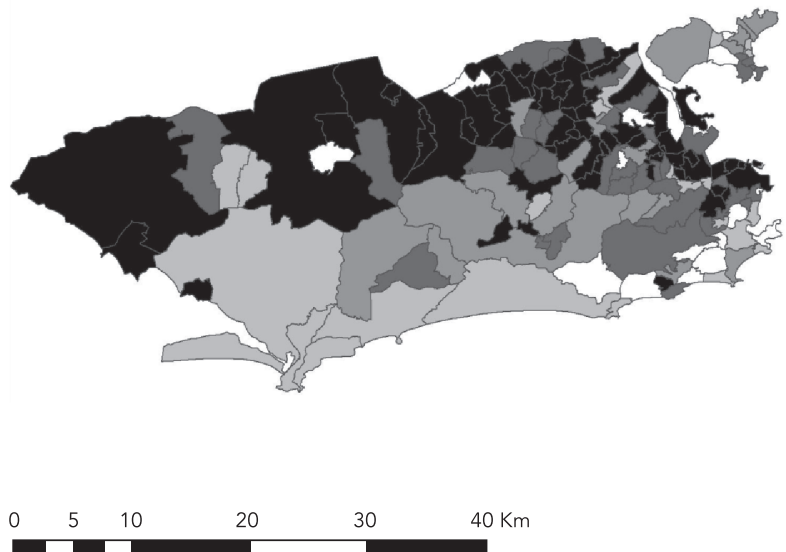

$\mathrm{UH}$

$0.00-0.77$

$0.77-0.81$

$0.81-0.84$

$0.84-0.88$

$0.88-1.00$ 2b) 2010
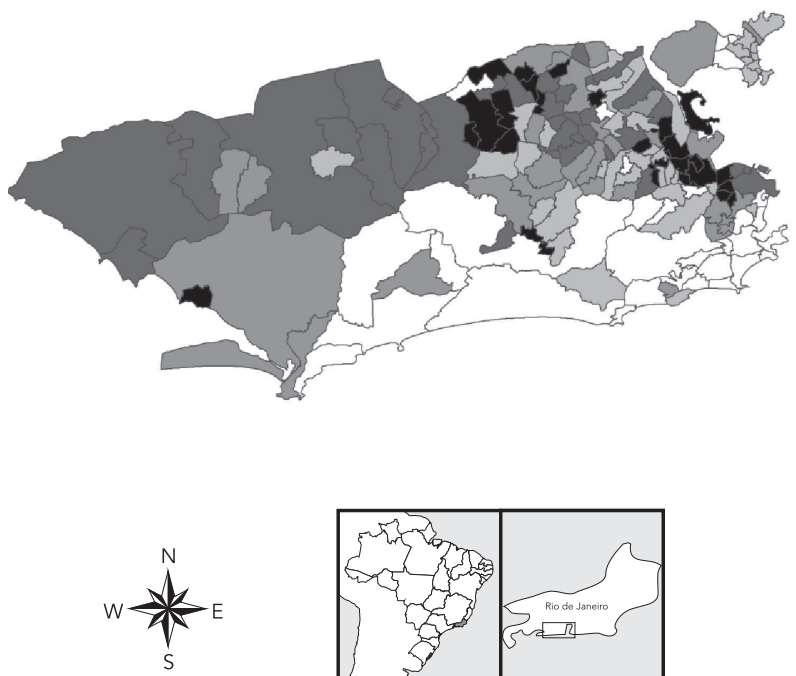

also the region of clusters of low index values, that is located in two large favela complexes.

However, the results augur well for the importance of the Family Health Program (FHP), which was initiated in 2008 in Rio de Janeiro, and which is expected to cover $70 \%$ of Rio's population by 2016 39,40. Until 2008, when the FHP was launched for Rio de Janeiro, there was no primary health care strategy covering the entire city. Health care access was therefore mainly a territorial problem. As a result secondary health care facilities such as emergency wards are overburdened with demand. Treatment in those facilities is focused on acute care rather than prevention and monitoring of chronic diseases, and patients do not develop a regular relationship with a family health physician as a first entry point. The health indicators that make up the UHI are diseases that are likely to respond well to the quality of primary health care (prevention, diagnosis, treatment). There is a need for central planning to allocate good quality health facilities and health care workers equally among the urban area. For future studies it would be of great interest to measure the impact of the FHP on health equity and the UHI could be a helpful tool for that.

\section{The horizontal dimension of inequity}

There are statistically significant correlation coefficients for the UHI with income-level, price of apartment per square meter and distance from the city center at the ward level. Those correlations do not provide strong analytical mechanisms, but they still suggest an association between health and market value at the urban population level. A health system that follows freemarket patterns may be prone to create inequalities driven by economic characteristics ${ }^{41}$. In this analysis the relationship between health and socioeconomic position was also demonstrated 42 . The number of pre-natal consults not only rep- 
Map displaying the local autocorrelation (Local Moran Index) for the ward-level Urban Health Index (UHI) values, Rio de Janeiro, Brazil, 2010, with statistically significant clusters of high index wards (HH) and low index wards (LL).
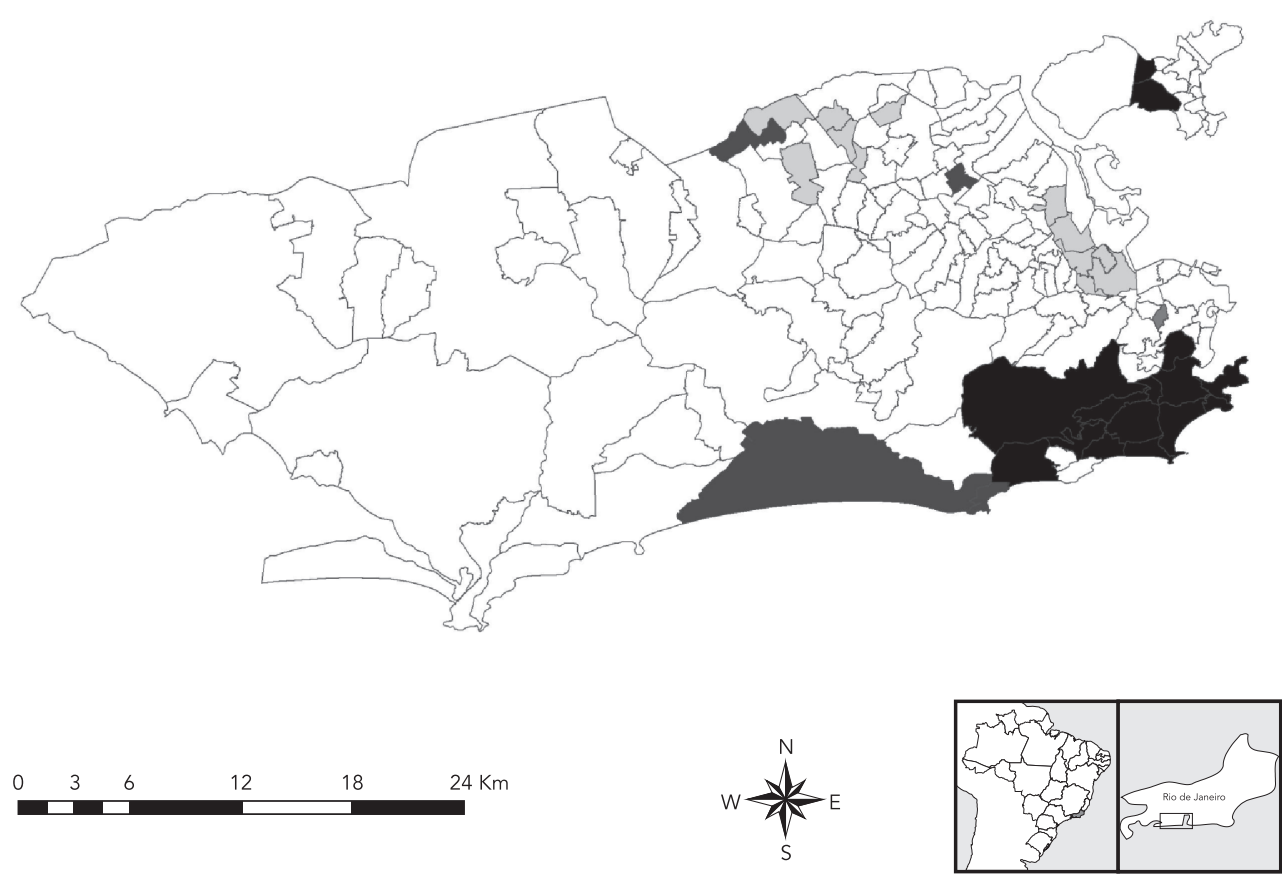

Not significant

$\mathrm{LL}$

LH

$\mathrm{HL}$

$\mathrm{HH}$

resents the effectiveness of prevention programs, but also indicates access to and coverage by the primary health care system. In particular wards with a young population structure exhibit low health index values. This raises questions about whether a whole future generation might be marginalized in terms of having opportunities to optimize health. The verified correlations between health outcomes and predominant skin color of a population represent a historic heritage of racial discrimination. Following the results it seems that in Rio de Janeiro population health may be influenced by the market value and social characteristics of the wards.

It is striking that mortality due to diabetes and infant mortality, two of the indicators which exhibited high correlations with social determinants, and which tend to be amenable to health care interventions - in other words, indicators which should be sensitive to social and health system improvements - show a trend of growing inequalities. Infant mortality is a focus of the FHP and is already well controlled on the regional-national level, but it seems to remain a problem at the urban level 43 . For diabetes, a rising burden of disease has been predicted, perhaps to alarming levels 15 and the UHI appears to capture that phenomenon. Tuberculosis, a main co-infection of HIV, also remains a challenge, perhaps due to persistent urban poverty-related factors, such as population density, poor sanitation and barriers to health care, which contrib- 
Bivariate correlation coefficients for the ward-level Urban Health Index (UHI) values 2010 and its eight component indicators with selected determinants aggregated by ward.

\begin{tabular}{|c|c|c|c|c|c|c|c|c|c|}
\hline & Diabetes & $\begin{array}{l}\text { Ischaemic } \\
\text { heart } \\
\text { disease }\end{array}$ & $\begin{array}{c}\text { Breast } \\
\text { and cervix } \\
\text { cancer }\end{array}$ & $\begin{array}{l}\text { Tuber- } \\
\text { culosis }\end{array}$ & HIV & $\begin{array}{c}\text { Traffic } \\
\text { accident }\end{array}$ & Homicide & $\begin{array}{l}\text { Infant } \\
\text { mortality }\end{array}$ & UHI \\
\hline \multicolumn{10}{|l|}{ Spearman } \\
\hline Distance from Lagoa & -0.46 * & -0.26 * & -0.078 & -0.01 & -0.10 & -0.12 & -0.40 * & -0.40 * & -0.30 * \\
\hline $\begin{array}{l}\text { Apartment price per square } \\
\text { meter } \star \star\end{array}$ & 0.57 * & 0.36 * & $0.19 * \star \star$ & 0.37 * & 0.27 * & 0.25 * & 0.58 * & 0.53 * & 0.54 * \\
\hline Population growth \# & -0.26 * & -0.045 & 0.13 & 0.04 & 0.01 & -0.04 & -0.14 & $-0.18 * \star \star$ & -0.09 \\
\hline \multicolumn{10}{|l|}{ Pearson } \\
\hline Mothers aged $<20$ years \#\# & -0.56 * & -0.25 * & -0.15 & $-0.42 *$ & -0.32 * & -0.24 * & -0.56 * & -0.63 * & -0.61 * \\
\hline Birth before week 37 \#\# & -0.01 & -0.13 & -0.13 & -0.16 & -0.11 & -0.05 & -0.11 & -0.04 & -0.17 \\
\hline $\begin{array}{l}\text { Mothers with } 4-7 \text { years of } \\
\text { education \#\# }\end{array}$ & $-0.50 *$ & $-0.27 *$ & -0.15 & $-0.49 *$ & $-0.34 *$ & $-0.29 *$ & $-0.47 *$ & $-0.58 *$ & -0.62 * \\
\hline $\begin{array}{l}\text { Mothers with > } 12 \text { years of } \\
\text { education \#\# }\end{array}$ & 0.65 * & 0.36 * & $0.20 \star \star \star$ & $0.43 *$ & 0.35 * & 0.30 * & 0.55 * & 0.62 * & 0.66 * \\
\hline $\begin{array}{l}\text { Mothers with }<3 \text { pre-natal } \\
\text { consultations \#\# }\end{array}$ & -0.48 * & -0.24 * & -0.13 & $-0.36 *$ & -0.27 * & -0.14 & -0.43 * & $-0.51 *$ & $-0.51 *$ \\
\hline $\begin{array}{l}\text { Mothers with > } 7 \text { pre-natal } \\
\text { consultations \#\# }\end{array}$ & 0.58 * & 0.27 * & 0.16 & 0.40 * & 0.31 * & 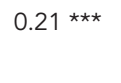 & 0.49 * & 0.59 * & 0.59 * \\
\hline Illiteracy \# & $-0.43 *$ & -0.06 & -0.02 & -0.36 * & -0.22 * & -0.13 & -0.29 * & -0.48 * & -0.41 * \\
\hline $\begin{array}{l}\text { Persons with income < } \\
\text { double mininum wage \# }\end{array}$ & $-0.61 *$ & $-0.29 *$ & $-0.17 \star \star \star$ & $-0.43 *$ & $-0.35 *$ & $-0.25 *$ & $-0.49 *$ & -0.58 * & -0.62 * \\
\hline $\begin{array}{l}\text { Persons with income } 5-10 \\
\text { times mininum wage \# }\end{array}$ & 0.63 * & 0.29 * & $0.18 * \star \star$ & $0.40 *$ & 0.31 * & $0.22 * \star \star$ & 0.54 * & 0.60 * & $0.61 *$ \\
\hline Black \# & $-0.51 *$ & $-0.21 \star \star \star$ & $-0.17 \star \star \star$ & $-0.39 *$ & -0.24 * & -0.15 & $-0.46 *$ & -0.66 * & -0.55 * \\
\hline White \# & 0.62 * & 0.27 * & 0.14 & 0.36 * & 0.28 * & $0.18 * \star \star$ & 0.53 * & 0.66 * & 0.60 * \\
\hline Mulatto \# & -0.62 * & -0.28 * & -0.11 & $-0.31 *$ & -0.27 * & $-0.18 * \star \star$ & -0.52 * & $-0.60 *$ & -0.57 * \\
\hline People aged $>60$ years \# & 0.52 * & $0.018^{\star \star \star}$ & 0.03 & 0.23 * & $0.17^{\star \star \star}$ & 0.15 & 0.37 * & 0.50 * & 0.42 * \\
\hline People aged $<20$ years \# & $-0.57 *$ & $-0.20 * \star \star$ & -0.08 & $-0.31 *$ &  & -0.17 & -0.44 * & -0.58 * & -0.50 * \\
\hline
\end{tabular}

* Statistically significant at $\mathrm{p}<0.01$ level (double-sided);

** Square meter price for apartment: source ZIS;

*** Statistically significant at $\mathrm{p}<0.05$ level (double-sided);

\# IBGE census data, 2010;

\#\# SINASC data, 2010.

ute to tuberculosis infection and progression 37. Inequality in HIV mortality is on the rise as well, despite the fact that Brazil has one of the biggest antiretroviral therapy programs among middleincome countries.

On the other hand, ischemic heart disease and breast-cervix cancer, two further indicators reflecting NCDs, show the biggest reductions in the disparity ratio. This could be a sign of improvements in living conditions and related lifestyle factors, as well as improved access to preventive and curative healthcare for these two conditions across the whole population. Another positive indication is the decrease of inequality in deaths due to external causes (i.e. homicide, traffic accident). This may reflect the effects of increased investments in public security or the impact of general socioeconomic developments at local and national levels 41 .

\section{Beyond the SDH - the role of the geographical space}

The World Health Organization (WHO) understands health as a product of underlying SDH. The urban space is also an SDH since it produces certain health outcomes by providing characteristic social circumstances 44 . In fact, social prob- 
lems are often found expressed in connection with geographical features. A core question is to what extent, and in what way, social background and place determine health outcomes. It is fundamental to understand space as a product of preexisting systematic inequalities that are generated by a complex interplay of political, economic and social systems 45 . The ward-level correlation analyses reflected the possible relationship between health, SDH and space, suggesting that spatial exclusion in health may also be characterized by socio-economic and racial patterns.

With the launch of Rio 2016 in combination with a growing public awareness 46 , Rio de Janeiro is faced with a great opportunity. It may lead to a process where politics, the health sector and civil society can align programs and policies towards closing the social and spatial equity gap. There is evidence to suggest that social programs, more so than investments in the built environment, can indeed shift the patterns of inequality 12,47. In the long run a better distribution of health services and health workers may be needed to extend coverage to the urban periphery and socially disregarded neighborhoods. The social structure of neighborhoods (e.g. by education level, income, percentage of elderly) will also need to be considered, as higher disease prevalence is found in socioeconomically disadvantaged wards.

\section{Methodological constraints on the intra-urban level}

The more disaggregated the data (i.e. the unit of analysis gets smaller) the higher the variances for mortality rates. There are statistical artifacts due to the random fluctuation of rates in low populated areas 20. Preliminary observations (data not presented) suggest that these are important issues to deal with which warrant further investigation to obtain statistically robust results. Indices, by their very nature, can obscure changes in the indicators. But their strength is their ability to capture the overall, more holistic, picture in a relatively simplistic manner. Also, high vari- ances for the mortality rates might be absorbed through the combination of several highly correlated component indicators. Here, methods such as selective age-adjustment and the fiveyear weighted moving averages were used as a first alternative to an empirical Bayesian smoothing approach, which would be likely to attenuate inter-spatial urban inequalities (i.e. between the wards) 48,49 . The five-year moving averages, however, may attenuate changes over time within a single geographic unit. In general it is recommended to keep the analyses as disaggregated as possible, to not lose some of the finer nuances and details of inequalities within urban settings. In the specific case of Rio de Janeiro, the ward level is still not detailed enough to capture variations at the neighborhood level, which incorporates micro areas with different income and social situations, such as favelas. There is still a necessity to collect comprehensive health data on that micro-urban level to allow for a more detailed perspective 50 .

\section{Conclusion}

In summary, this study examined intra-urban health inequalities in Rio de Janeiro using an index composed of eight health indicators. The main objective was to reveal the trends in health inequality including their spatial patterns and certain links to SDH - at a moment when the city is in a state of urban renewal. The UHI and its applications appear to be a flexible approach for measuring equity within urban settings. Evidence was found that the health equity situation has improved in Rio de Janeiro since 2002 as wards at the lower end of the inequality distribution improved but a substantial spatial divide is still visible in terms of health development. Results suggest that the spatial inequalities adapt socioeconomic and market value patterns. The FHP provides a holistic approach that might be able to achieve better health equity within Rio de Janeiro's territory. 


\section{Resumen}

Se utilizó un índice de salud urbana para cuantificar desigualdades en el ámbito de la salud en Río de Janeiro, Brasil, 2002 a 2010. Se han generado ocho indicadores de salud a nivel de barrios, utilizando datos de mortalidad. Los indicadores fueron combinados para formar el índice. La distribución ordenada de los valores del indice ofrece información de la desigualdad, a través de la relación entre los extremos y el gradiente de los valores medios. A lo largo de la década la proporción de los extremos disminuyó en 2010, en comparación con 2002 (1,57 vs. 1,32), al igual que el gradiente de los valores medios (0,23 vs. 0,16). La división espacial entre el opulento sur y el norte desfavorecido es todavía visible. Los valores del índice se correlacionan con los indicadores socioeconómicos y urbanos, como el precio de los apartamentos (0,54, $p<0,01)$, la baja educación materna $(-0.61, p<0.01)$, baja renta $(-0,62, p<0,01)$ y la población afrobrasileña $(-0,55, p<$ $0,01)$. Los resultados sugieren que la equidad en salud ha mejorado en Río de Janeiro en la última década, aunque los patrones familiares de desigualdad espacial permanecen.

Indicadores de Salud; Desigualdades en la Salud; Salud Urbana

\section{Contributors}

M. Bortz contributed to the conception and design, acquisition of data, analysis and interpretation of data, drafting the article and revising it critically for important intellectual content, and final approval of the version to be published. M. Kano contributed to the conception and design, methodology, drafting of paper, and approval of the version to be published. H. Ramroth contributed to the conception and design and drafting of the paper. C. Barcellos contributed to the conception and design, drafting of the paper, and acquisition of data and interpretation. S. R. Weaver contributed to the conception and design, drafting of the paper, and approval of the version to be published. R. Rothenberg contributed to the conception and design, methodology, and approval of the version to be published. M. Magalhães contributed to the methodology and approval of the version to be published.

\section{Acknowledgments}

This study was the result of a collaboration between the WHO Centre for Health Development (Kobe, Japan), the Georgia State University School of Public Health (Atlanta, USA), the Institute of Scientific and Technological Communication and Information in Health, Oswaldo Cruz Foundation (Rio de Janeiro, Brazil) and the Medical School at Heidelberg University Institute of Public Health (Heidelberg, Germany). Research supported in this publication was partially supported by the National Institute of Minority Health and Health Disparities of the National Institutes of Health under award number 1P20MD004806. The content is solely the responsibility of the authors and does not necessarily represent the official views of the National Institutes of Health or the World Health Organization.

\section{References}

1. Cohen B. Urban growth in developing countries: a review of current trends and a caution regarding existing forecasts. World Dev 2004; 32:23-51.

2. De Oliveira MP. Projeto Rio Cidade: intervenção urbanística, planejamento urbano e restrição à cidadania na cidade do Rio de Janeiro. Scripta Nova, Revista Electrónica de Geografía y Ciencias Sociales 2008; $12(270 \mathrm{Pt} 117)$. http://www.ub.es/ geocrit/sn/sn-270/sn-270-117.htm.

3. Cornwall A, Shankland A. Engaging citizens: lessons from building Brazil's national health system. Soc Sci Med 2008; 66:2173-84.
4. Victora CG, Barreto ML, Leal MC, Monteiro CA, Schmidt MI, Paim J, et al. Health conditions and health-policy innovations in Brazil: the way forward. Lancet 2011; 377:2042-53.

5. Rocha R, Soares RR. Evaluating the impact of community-based health interventions: evidence from Brazil's Family Health Program. Health Econ 2010; 19:126-58

6. Ferreira A. Influência europeia ou mera cópia? A produção do espaço no Rio de Janeiro. Scripta Nova, Revista Electrónica de Geografía y Ciencias Sociales 2012; 16(418 Pt 42). http://www.ub.es/ge ocrit/sn/sn-418/sn-418-42.htm. 
7. McCartney G, Thomas S, Thomson H, Scott J, Hamilton V, Hanlon P, et al. The health and socioeconomic impacts of major multi-sport events: systematic review (1978-2008). BMJ 2010; 340:c2369.

8. Soares F, Soares YSD. The socio-economic impact of favela-bairro: what do the data say? Washington DC: Interamerican Development Bank; 2005. (OVE Working Paper, 0805).

9. Barreto ML, Genser B, Strina A, Teixeira MG, Assis $\mathrm{AM}$, Rego RF, et al. Impact of a citywide sanitation program in Northeast Brazil on intestinal parasites infection in young children. Environ Health Perspect 2010; 118:1637-42.

10. Paim J, Travassos C, Almeida C, Bahia L, Macinko J. The Brazilian health system: history, advances, and challenges. Lancet 2011; 377:1778-97.

11. Victora CG, Aquino EML, Leal MC, Monteiro CA, Barros FC, Szwarcwald CL. Maternal and child health in Brazil: progress and challenges. Lancet 2011; 377:1863-76.

12. Barreto ML, Teixeira MG, Bastos FI, Ximenes RA, Barata RB, Rodrigues LC. Successes and failures in the control of infectious diseases in Brazil: social and environmental context, policies, interventions, and research needs. Lancet 2011; 377: 1877-89.

13. Barcellos C, Lowe R. Expansion of the dengue transmission area in Brazil: the role of climate and cities. Trop Med Int Health 2014; 19:159-68.

14. Barcellos C, Acosta LM, Lisboa E, Bastos FI. Surveillance of mother-to-child HIV transmission: socioeconomic and health care coverage indicators. Rev Saúde Pública 2009; 43:1006-14.

15. Schmidt MI, Duncan BB, Azevedo e Silva G, Menezes AM, Monteiro CA, Barreto SM, et al. Chronic non-communicable diseases in Brazil: burden and current challenges. Lancet 2011; 377:1949-61.

16. Reichenheim ME, de Souza ER, Moraes CL, de Mello Jorge MH, da Silva CM, de Souza Minayo MC. Violence and injuries in Brazil: the effect, progress made, and challenges ahead. Lancet 2011; 377:1962-75.

17. Andrade CLT, Szwarcwald CL, Gama SGN, Leal MC. Desigualdades sócio-econômicas do baixo peso ao nascer e da mortalidade perinatal no $\mathrm{Mu}$ nicípio do Rio de Janeiro, 2001. Cad Saúde Pública 2004; 20 Suppl 1:S44-51.

18. d'Orsi E, Chor D, Giffin K, Angulo-Tuesta A, Barbosa GP, Gama AS, et al. Quality of birth care in maternity hospitals of Rio de Janeiro, Brazil. Rev Saúde Pública 2005; 39:645-54.

19. Friche AAL, Caiaffa WT, César CC, Goulart LMF, Almeida MCM. Indicadores de saúde materno infantil em Belo Horizonte, Minas Gerais, Brasil, 2001: análise dos diferenciais intra-urbanos. Cad Saúde Pública 2006; 22:1955-65.

20. Szwarcwald CL, da Mota JC, Damacena GN, Pereira TG. Health inequalities in Rio de Janeiro, Brazil: lower healthy life expectancy in socioeconomically disadvantaged areas. Am J Public Health 2011; 101:517-23.

21. Szwarcwald CL, de Andrade CLT, Bastos FI. Income inequality, residential poverty clustering and infant mortality: a study in Rio de Janeiro, Brazil. Soc Sci Med 2002; 55:2083-92.
22. Tomazelli J, Czeresnia D, Barcellos C. Distribuição dos casos de AIDS em mulheres no Rio de Janeiro, de 1982 a 1997: uma análise espacial. Cad Saúde Pública 2003; 19:1049-61.

23. Sheiham A. Closing the gap in a generation: health equity through action on the social determinants of health. A Report of the WHO Commission on Social Determinants of Health (CSDH) 2008. Community Dent Health 2009; 26:2-3.

24. Ompad DC, Galea S, Caiaffa WT, Vlahov D. Social determinants of the health of urban populations: methodologic considerations. J Urban Health 2007; 84 Suppl 1:42-53.

25. Barcellos C. Os indicadores da pobreza e a pobreza dos indicadores: uma abordagem geográfica das desigualdades sociais em saúde. In: Barcellos C, editor. A geografia e o contexto dos problemas de saúde. v. 1. Rio de Janeiro: ABRASCO; 2008. p. 107-39.

26. Rothenberg R, Weaver SR, Dai D, Stauber C, Prasad A, Kano M. A flexible urban health index for small area disparities. J Urban Health 2014; 91:823-35.

27. McGranahan G. Urban environments, wealth and health: shifting burdens and possible responses in low and middle-income nations. London: International Institute for Environment and Development; 2007.

28. Vlahov D, Galea S, Freudenberg N. The urban health "advantage". J Urban Health 2005; 82:1-4.

29. Kleinert S, Horton R. Brazil: towards sustainability and equity in health. Lancet 2001; 377:1721-2.

30. World Health Organization. Urban HEART: Urban Health Equity Assessment and Response Tool. User manual. Kobe: World Health Organization Centre for Health Development; 2010.

31. Julious S, Nicholl J, George S. Why do we continue to use standardized mortality ratios for small area comparisons? J Public Health Med 2001; 23:40-6.

32. Sagar A, Najam A. The human development index: a critical review. Ecol Econ 1998; 25:249-64.

33. Anselin L. Local indicators of spatial association LISA. Geogr Anal 1995; 27:93-115.

34. Cunha e Silva DC, Lourenço RW, Cordeiro RC, Cordeiro MRD. Análise da relação entre a distribuição espacial das morbidades por obesidade e hipertensão arterial para o estado de São Paulo, Brasil, de 2000 a 2010. Ciênc Saúde Coletiva 2014; 19:1709-19.

35. Rasella D, Aquino R, Santos CA, Paes-Sousa R, Barreto ML. Effect of a conditional cash transfer programme on childhood mortality: a nationwide analysis of Brazilian municipalities. Lancet 2013; 382:57-64.

36. Magalhaes R, Bodstein R, Coelho AV, Nogueira MF, Bocca C. The Bolsa Familia (family grant) program in Manguinhos: challenges and lessons learned in a case study Implementation process: development of strategies and evidence. Glob Health Promot 2011; 18:13-5.

37. Golub J, Saraceni V, Cavalcante SC, Pacheco AG, Moulton LH, King BS, et al. The impact of antiretroviral therapy and isoniazid preventive therapy on tuberculosis incidence in HIV-infected patients in Rio de Janeiro, Brazil. AIDS 2007; 21:1441-8. 
38. Steinbrink M. Festifavelisation: mega-events, slums and strategic city-staging - the example of Rio de Janeiro. Erde 2013; 144:129-45.

39. Starfield B, Gervas J, Mangin D. Clinical care and health disparities. Annu Rev Public Health 2012; 33:89-106.

40. Escorel S, Giovanella L, Magalhaes de Mendonca MH, Maia Senna MC. The Family Health Program and the construction of a new model for primary care in Brazil. Rev Panam Salud Pública 2007; 21:164-76.

41. Kentikelenis A, Karanikolos M, Reeves A, McKee M, Stuckler D. Greece's health crisis: from austerity to denialism. Lancet 2014; 383:748-53.

42. Caiaffa WT, Almeida MCM, Oliveira CDL, Friche AAL, Matos SG, Dias MAS, et al. The urban environment from the health perspective: the case of Belo Horizonte, Minas Gerais, Brazil. Cad Saúde Pública 2005; 21:958-67.

43. Aquino R, De Oliveira NF, Barreto ML. Impact of the Family Health Program on infant mortality in Brazilian municipalities. Am J Public Health 2009; 99:87-93.

44. Diez Roux A, Green Franklin T, Alazraqui M, Spinelli $\mathrm{H}$. Intraurban variations in adult mortality in a large Latin American city. J Urban Health 2007; 84:319-33.
45. Caiaffa W, Ferreira FR, Ferreira AD, Oliveira CD, Camargos VP, Prioetti FA. Saúde urbana: "a cidade é uma estranha senhora, que hoje sorri e amanhã te devora". Ciênc Saúde Coletiva 2008; 13:1785-96.

46. Conde M, Jazeel T. Kicking off in Brazil: manifesting democracy. Journal of Latin American Cultural Studies 2013; 22:437-50.

47. Stephens C. Revisiting urban health and social inequalities: the devil is in the detail and the solution is in all of us. Environ Urban 2011; 23:29-40.

48. Souza WV, Carvalho MS, Albuquerque MF, Barcellos CC, Ximenes RA. Tuberculosis in intra-urban settings: a Bayesian approach. Trop Med Int Health 2007; 12:323-30.

49. Puigpinós-Riera R, Marí-Dell’Olmo M, Gotsens M, Borrel C, Serral G, Ascaso C, et al. Cancer mortality inequalities in urban areas: a Bayesian small area analysis in Spanish cities. Int J Health Geogr 2011; 10:6.

50. Santos SM, Chor D, Werneck GL. Demarcation of local neighborhoods to study relations between contextual factors and health. Int J Health Geogr 2010; 9:34.

Submitted on 26/May/2014

Final version resubmitted on 16/Sep/2014

Approved on 03/Oct/2014 